\title{
Announcements
}

\section{The American Association for Thoracic Surgery}

\author{
The American Association for Thoracic Surgery Graham Traveling Fellowship, 2006-2007
}

\section{STIPEND $\$ 75,000$}

$\mathrm{T}$ The American Association for Thoracic Surgery Evarts A. Graham Memorial Traveling Fellowship was established in 1951 by The American Association for Thoracic Surgery. Administered through the Graham Educational Research Foundation Fellowship grants support study by young cardiothoracic surgeons from outside North America at sites of their choice within North America and include travel between sites. Goals of the program are to broaden overall training and increase international contacts. Each Fellow should plan to have one primary center for his/her activities where he/she should spend from six to nine months. The Fellow should have identified an individual at that center who will act as his/her sponsor and assist in planning the course of study at the host institution and at other institutions. In addition to the primary center, the Fellow is encouraged to plan to spend shorter periods of time at other secondary centers to enhance the Fellowship experience.

Awards are made to surgeons of unique promise who have been regarded as having the potential for later international thoracic surgical leadership. Since the inception of the Graham Fellowship, 50 young surgeons from 25 countries have completed the Fellowship.

The Fellowship provides a stipend of $\$ 75,000$. The Fellowship also provides two round-trip coach air fares from the recipient's country to his/her primary center. The dates of the beginning of the Fellowship year should be scheduled to coincide with the Annual Meeting of The American Association for Thoracic Surgery in Philadelphia, Pennsylvania, in April 2006. The Fellow will be introduced to the AATS membership at this meeting.

The Fellow should become involved predominantly with observation, consultation, teaching, and research at a variety of thoracic surgical training centers during the twelve months. Patient contact will be determined by the sponsoring surgeon and will conform to the regulations and licensing requirements of the state, province, or country in which he/she is studying. A candidate should have completed his/her formal training in general surgery and in thoracic and cardiovascular surgery, but he/she should not have reached a senior position. Candidates must be sufficiently proficient in English to realize the full benefits of the Fellowship. Candidates should not have received significant training in North America prior to making application for this award.

Applications for the Fellowship are available from:

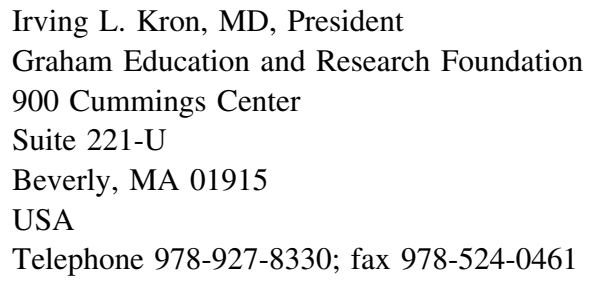

For additional information and to download an application, please visit the AATS Web site at: www.aats.org/academic/ fellowships.

Completed applications must be returned no later than July 1, 2005. The selected candidate will be notified by December 15, 2005.

\section{The American Association for Thoracic Surgery John W. Kirklin Research Scholarship, 2006-2008}

\section{STIPEND \$75,000 PER YEAR}

$\mathrm{T}$ The American Association for Thoracic Surgery announces the AATS John W. Kirklin Research Scholarship to provide an opportunity for research, training, and experience for a North American surgeon committed to pursuing an academic career in cardiothoracic surgery. The scholarship will be funded by the Association and administered by the Graham Education and Research Foundation. 
The research program must be undertaken within the first three years after completion of an approved cardiothoracic residency. Applications for the scholarship may be submitted during the candidate's final year of cardiothoracic residency or during his or her first two years in an academic position. The duration of the scholarship is to be two years.

The yearly stipend shall be $\$ 75,000$ paid to the host institution. In addition, a grant of $\$ 5,000$ per year shall be made for support of research supplies, travel, and other legitimate academic expenses of the scholar. Applications for the scholarship are available from the Secretary of The American Association for Thoracic Surgery. The application will consist of three components:

1. The candidate must submit a proposal for the research to be undertaken and a statement of career plans and how the research activity will relate to the candidate's academic career.

2. The Director of the laboratory in the institution at which the research will be performed shall submit an endorsement of the proposal and indicate the facilities and degree of support available for the candidate's research.

3. The Chair of the candidate's department shall submit his or her endorsement of the proposal and indicate the willingness of the institution to provide an academic appointment for the candidate upon completion of the scholarship.

The application and its three components shall be submitted to the Secretary of The American Association for Thoracic Surgery by July 1, 2005. Announcement of the award will be made by the President of The American Association for Thoracic Surgery by December 15, 2005. The Scholarship will begin July 1, 2006. Following completion of the two-year program the scholar shall submit a written report of his/her research activities to the membership of the Association.

Applications for the scholarship are available from:

Irving L. Kron, MD, Secretary

The American Association for Thoracic Surgery

900 Cummings Center

Suite 221-U

Beverly, MA 01915

978-927-8330: fax 978-524-0461

Applications may be downloaded from the AATS Web site at: http://www.aats.org/research/grants.

\section{Announcement of 2006 Annual Meeting}

$\mathrm{T}$ The Eighty-sixth Annual Meeting of The American Association for Thoracic Surgery will be held April 29-May 3, 2006, in Philadelphia, Pennsylvania, at the Pennsylvania Convention Center. The meeting of the Association is open to all physicians. House Officers and Fellows will be admitted without payment of a registration fee upon presentation of a letter from their Chief of Service either during preregistration or at the time of registration. Nonmember physicians are required to pay a $\$ 250$ preregistration fee up to March 24, 2006. After that date a registration fee of $\$ 300$ will be required. Members, nonmember phy- sicians, and invited speakers will have the privilege of discussing papers.

\section{Requests for Preregistration Forms and Hotel Reservations}

Information on the 2006 Annual Meeting, including registration, hotel accommodations, and the social program, will be available in December 2005. Requests should be forwarded directly to:

\author{
American Association for Thoracic Surgery \\ 900 Cummings Center \\ Suite 221-U \\ Beverly, MA 01915 \\ 978-927-8330; fax: 978-524-8890 \\ e-mail: aats@prri.com \\ Registration and hotel information is available on our Web site \\ at www.aats.org.
}

\section{Call for Abstracts}

Authors submitting abstracts for the 2006 Annual Meeting must use electronic submission. Abstracts submitted electronically for consideration for presentation at the 2006 meeting must have been received on or before October 10, 2005. Abstracts received after the deadline will not be considered by the Program Committee. The work must not have been presented or reported elsewhere.

\section{Electronic Submission}

Deadline for submission is October 10, 2005. Please submit your abstract via the World Wide Web. All abstract submissions must be in the structured format as required by The Journal of Thoracic and Cardiovascular Surgery. The structured abstract is to contain the following major headings: Objective(s), Methods, Results, and Conclusions, and it should clearly reflect the content of the completed paper. No reference should be made on the abstract to the names or institutions of the authors.

Receipt of each abstract will be acknowledged by e-mail. Notification of the decision of the Program Committee will be distributed by the end of December 2005.

Essayists selected for the program are reminded that papers presented at the meeting are to be submitted for consideration for publication to The Journal of Thoracic and Cardiovascular Surgery and must be submitted to the JTCVS via the Internet prior to the Annual Meeting. Papers that are selected by the AATS Program Committee may not be presented or published elsewhere prior to the Annual Meeting in 2006.

\section{Walton Lillehei Resident Forum}

The C. Walton Lillehei Resident Forum will be held on Sunday, April 30, 2006. Made possible through an educational grant from St Jude Medical, the Forum will consist of the presentation of original work by residents in thoracic surgical training programs around the world. Abstracts submitted for the award should follow the guidelines of abstract submission for electronic submission noted above. The abstracts submitted for consideration for this Forum will be evaluated by the Program Committee and eight will be selected for presentation during the forum. Each of the selected authors will receive round-trip travel and accommodations for the duration of the AATS annual meeting. Additionally, one presen- 
tation will be selected by the Program Committee to receive the AATS C. Walton Lillehei Residents' Award, a \$5000 prize. Thoracic Surgery Program Directors are urged to have their residents participate in this Forum.

Abstract Deadline-Abstracts received after the deadline will not be considered

Electronic Submission Only: October 10, 2005

\section{Applications for Membership}

Applications for membership in the Association must have been received by the Membership Committee Chairman no later than November 2005. Applications received after that date will be deferred automatically for consideration until the 2007 meeting.

Applications for membership may be issued to sponsoring members of the Association and are also available to potential candidates who have identified member sponsors. Application forms are available from:

Chairman, Membership Committee

American Association for Thoracic Surgery

900 Cummings Center

Suite 221-U

Beverly, MA 01915

978-927-8330; fax: 978-524-8890

e-mail: aats@prri.com

Irving L. Kron, MD, Secretary

\section{The Western Thoracic Surgical Association}

\section{Announcement of 2005 Annual Meeting}

$\mathrm{T}$ The Thirty-first Annual Meeting of The Western Thoracic Surgical Association will be held June 22-25, 2005, at the Empress Hotel in Victoria, British Columbia, Canada. The scientific sessions are open to all duly qualified physicians. Participation in other Association activities for members, invited guests, and program participants will require payment of a social registration fee.

\section{Requests for Meeting Information}

Meeting preregistration and hotel registration forms are available from:

The Western Thoracic Surgical Association

900 Cummings Center
Suite 221-U

Beverly, MA 01915

978-927-8330; fax: 978-524-8890

wtsa@prri.com

\section{Material for the Program}

Scientific papers will be considered from members and nonmembers. Member sponsorship is not necessary.

For the 2005 Annual Meeting, abstract submission opened on November 12, 2004. All abstracts must be submitted electronically via the WTSA Web site. Information and a link to the submission site was posted on the Web site about November 12. A Call for Abstracts also was mailed out around that time. Abstracts of proposed papers must have been submitted on or before January 7, 2005.

Successful essayists must send the complete manuscript directly to The Journal of Thoracic and Cardiovascular Surgery and must not exceed 3000 words without illustrations. Electronic submissions are to be sent to: http://jtcvs.editorialmanager.com where complete instructions are also available. The essay length must be reduced appropriately when figures or tables are included.

\section{Samson Resident Prize Essay}

The Association offers a prize for the best manuscript on a topic of interest to thoracic surgeons in honor of Paul C. Samson, MD. Candidates for the prize must be in a training program in the United States or Canada. The one essayist whose abstract, manuscript, and presentation are judged most outstanding will receive a $\$ 2000$ cash award following the presentation of all papers in Victoria. The conditions for abstract submission, presentation, and publication as described above will apply. The authors of the abstracts chosen for the program will make up the finalists and were notified by mid-February 2005 that they must submit six completed manuscripts for review by the Prize Essay Committee. The Prize Essay committee will make its selection following the presentation of all papers.

\section{Application for Membership}

Applications for membership in the Association must have been received by the Membership Committee Chairman no later than March 1, 2005, to be considered at the following annual meeting. Applicants must be sponsored by three members of the Association who are not members of the Membership Committee. Application forms will be issued only to sponsoring members.

Address correspondence to:

Chairman, Membership Committee

The Western Thoracic Surgical Association

900 Cummings Center

Suite 221-U

Beverly, MA 01915

978-927-8330; fax: 978-524-8890

wtsa@prri.com 


\section{The American Board of Thoracic Surgery}

\section{Notices}

$\mathrm{T}$ The part I (written) examination will be held on December 5, 2005. It is planned that this examination will be given at multiple sites throughout the United States using an electronic format. The closing date for registration is August 1 each year. Those wishing to be considered for examination must apply online at www.abts.org.

To be admissible for the Part II (oral) examination, a candidate must have successfully completed the Part I (written) examination.

A candidate applying for admission to the certifying examination must fulfill all the requirements of the Board in force at the time the application is received. Please address all communications to the American Board of Thoracic Surgery, 633 North St Clair Street, Suite 2320, Chicago, IL 60611 (telephone: 312-202-5900).

\section{Requirements for Recertification/Maintenance of Certification}

$\mathrm{D}$ iplomates of the American Board of Thoracic Surgery who plan to participate in the Recertification/Maintenance of Certification process must hold an active medical license and must hold clinical privileges in thoracic surgery. In addition, a valid certificate is an absolute requirement for entrance into the recertification/maintenance of certification process. If your certificate has expired, the only pathway for renewal of a certificate is to take and pass the Part I (written) and the Part II (oral) certifying examinations.

The American Board of Thoracic Surgery will no longer publish the names of individuals who have not recertified in the
American Board of Medical Specialties directories. The Diplomate's name will be published upon successful completion of the recertification/maintenance of certification process.

The CME requirements include 70 Category I credits in either cardiothoracic surgery or general surgery earned during the 2 years prior to application. SESATS and SESAPS are the only selfinstructional materials allowed for credit. Category II credits are not allowed. The Physicians Recognition Award for recertifying in general surgery is not allowed in fulfillment of the CME requirements. Interested individuals should refer to the Booklet of Information for a complete description of acceptable CME credits.

Diplomates should maintain a documented list of their major cases performed during the year prior to application for recertification. This practice review should consist of 1 year's consecutive major operative experiences. If more than 100 cases occur in 1 year, only 100 should be listed.

Candidates for recertification/maintenance of certification will be required to complete all sections of the SESATS self-assessment examination. It is not necessary for candidates to purchase SESATS individually because it will be sent to candidates after their application has been approved.

Diplomates may recertify the year their certificate expires, or if they wish to do so, they may recertify up to 2 years before it expires. However, the new certificate will be dated 10 years from the date of expiration of their original certificate or most recent recertification certificate. In other words, recertifying early does not alter the 10-year validation.

Recertification/maintenance of certification is also open to Diplomates with an unlimited certificate and will in no way affect the validity of their original certificate.

The deadline for submission of applications for the recertification/maintenance of certification process is May 10 each year. A brochure outlining the rules and requirements for recertification/ maintenance of certification in thoracic surgery is available upon request from the American Board of Thoracic Surgery, 633 North St Clair Street, Suite 2320, Chicago, IL 60611; telephone: 312202-5900; fax: 312-202-5960; E-mail: info@abts.org. The booklet is also published on the Web site: www.abts.org.

\section{Targeted}

The Journal of Thoracic and Cardiovascular Surgery gives you two tables of contents.

The condensed table of contents tells you at a glance what topics and authors are presented each month. The expanded table of contents gives you a brief abstract of each article. You select only those articles of most interest to you for further reading. 